\title{
Noble Crayfish Are More Sensitive to Terbuthylazine than Parthenogenetic Marbled Crayfish
}

\author{
Jan Laurenz $\mathbb{D} \cdot$ Lena Lietz • Heinz Brendelberger • \\ Kai Lehmann $(\mathbb{D} \cdot$ Arne Georg (1)
}

Received: 20 July 2020 / Accepted: 3 November 2020 /Published online: 11 November 2020

(C) The Author(s) 2020

\begin{abstract}
We investigated the sensitivity of two freshwater crayfish species (Astacus astacus and Procambarus virginalis) during embryonic development to chronic exposure to the herbicide terbuthylazine under laboratory conditions. The assessed parameters included time of embryonic development, survival rate, hatching weight and histopathology of hepatopancreas. $\mathrm{LC}_{50}$ (median lethal concentration) and $\mathrm{ED}_{50}$ (median effective concentration) were estimated. We were able to determine effects of terbuthylazine for every investigated parameter. For noble crayfish, the $\mathrm{LC}_{50}$ value after 45 days was $0.11 \mathrm{mg} / \mathrm{L}$, and the histology of the hepatopancreas showed effects starting from $0.025 \mathrm{mg} / \mathrm{L}$. Other parameters revealed effects starting at concentrations of $1.6 \mathrm{mg} / \mathrm{L}$ for weight and $6.4 \mathrm{mg} / \mathrm{L}$ for embryonic development time and hatching rate. Marbled crayfish only showed effects concerning the hatching rate and survival rate at concentrations without a clear doseeffects curve. As a conclusion, our data shows the risk of terbuthylazine in existing concentrations in freshwater ecosystems to non-target organisms and also the need of toxicological studies on directly affected species in addition to the use of model organisms.
\end{abstract}

Keywords Marbled crayfish - Noble crayfish . Juveniles $\cdot$ Terbuthylazine $\cdot$ Embryonic

J. Laurenz $(\bowtie) \cdot$ L. Lietz $\cdot$ H. Brendelberger •

K. Lehmann · A. Georg

Limnology, Zoological Institute, Christian-Albrechts-University,

Kiel, Germany

e-mail: jlaurenz@zoologie.uni-kiel.de

\section{Introduction}

Terbuthylazine (TBA) is a chlorotriazine used worldwide as a pre-emergence herbicide in corn farming. This leads to peaks of TBA concentrations in natural water bodies during March and April. Its use is of emerging concern because of its persistence, toxicity and proven endocrine disruption in wildlife and humans (Tasca et al. 2019). It is also one of the most frequently detected pesticides in natural waters (Herrero-Hernández et al. 2017). Concentrations of more than $34.0 \mu \mathrm{g} / \mathrm{L}$ have been found in European freshwater bodies (Stepanova et al. 2012). Despite its prevalence in European ecosystems, little is known about the effects of this pollutant on most freshwater invertebrate species.

Freshwater crayfish affect nearly every trophic level of their habitat and influence their structural environment due to their burrowing activity. Therefore, these largest invertebrates of freshwater bodies are called "keystone species" and "ecosystem engineers" (Weinländer and Füreder 2016). Due to decreasing populations, the habitat directive protects all native freshwater crayfish species in Europe (European Communities 1992). Nevertheless, these species are highly endangered. Invasive species, the crayfish plague (Aphanomyces astaci), structural stress and chemical loads cause population decline (Chucholl 2011; Svobodová et al. 2012; Vladica Simić et al. 2015). The influences in particular of presumed toxic chemicals on sensitive life stages affect population recruitment and dynamics. One highly sensitive life stage is the development of crayfish embryos (Khan and Nugegoda 
2007). During this period, between November and June (Ackerfors 1999), the embryonic individual is exposed to the environment and its possibly harmful substances without the possibility of active avoidance. Because of its usage as a pre-emergence herbicide, the highest concentrations of TBA are detected at the beginning of spring and therefore in this sensitive development period of freshwater crayfish (Lorente et al. 2015).

For this reason, we examined the effects of TBA on the embryonic development of two freshwater crayfish species. We used marbled crayfish (Procambarus virginalis, Lyko, 2017) to test its suitability as a model organism to represent other crayfish in future toxicological studies. One female can produce up to 700 eggs every $8-9$ weeks. The offspring is genetically identical due to the species' parthenogenetic reproduction strategy (Vogt et al. 2004; Vogt 2015), thus providing a predictable and continuous supply of clonal eggs and making this species a suitable model organism for higher invertebrates with a longer embryonic development (Hossain et al. 2018; Vogt 2018). The second organism we studied was the native noble crayfish (Astacus astacus, Linnaeus, 1758), as it is especially suitable for our study due to its natural habitats (lower sections of streams, lakes, etc.), which are often influenced by agricultural drainage and sewage (Skurdal and Taugbøl 2002).

Parameters that can indicate lethal and sublethal effects of herbicides on the reproduction of freshwater crayfish are embryonic development, survival rate, hatching weight and the histopathology of the hepatopancreas of the juveniles (Velisek et al. 2013). Changes in the first three parameters directly influence the development of populations. Hepatopancreas tissue is used for monitoring the health of crayfish and can indicate diseases and exposure to harmful substances (Xiao et al. 2014; Velisek et al. 2017). The hepatopancreas is the site of nutrient absorption, digestion, synthesis and secretion of digestive enzymes and reserve storage in decapods (Xiao et al. 2014; Johnston et al. 1998; Calvo et al. 2011). It is formed of numerous tubules separated by connective tissues (Abd El-Atti et al. 2019) and consists of a lumen, membranes and four types of epithelial cells: resorptive lipid cells ( $\mathrm{R}$ cell) for nutrient intake, blister-like secretory cells (B cell) to channel off harmful substances, fibrillar cells ( $\mathrm{F}$ cell) as connecting tissue and embryonic cells (E cell). This means, changes in $\mathrm{R}$ cells would indicate a higher or lower intake of nutrients, changes in $\mathrm{B}$ cells would indicate a higher or lower outtake of harmful substances, whereas changes in the other two types would indicate problems in the biosynthesis of the individual. We hypothesise that TBA exposure influences the aforementioned parameters in both species of freshwater crayfish, noble- and marbled crayfish, and that the marbled crayfish embryos and noble crayfish embryos are affected by the herbicide in a similar way.

\section{Material and Methods}

\subsection{Chemicals}

Terbuthylazine was obtained from Sigma-Aldrich, Germany, in $98 \%$ purity. Concentrations were chosen to cover the range from concentrations occurring in surface waters to known effective concentrations from other taxa (Shehata et al. 1997; Schramm et al. 1998; Cedergreen and Streibig 2005) as follows: $0.0 \mathrm{mg} / \mathrm{L}$; $0.025 \mathrm{mg} / \mathrm{L} ; 0.1 \mathrm{mg} / \mathrm{L} ; 0.4 \mathrm{mg} / \mathrm{L} ; 1.6 \mathrm{mg} / \mathrm{L} ; 6.4 \mathrm{mg} / \mathrm{L}$ and $12.8 \mathrm{mg} / \mathrm{L}$. Due to low solubility $\left(5 \mathrm{mg} / \mathrm{L}\right.$ in $20^{\circ} \mathrm{C}$ ), TBA was dissolved in dimethylsulfoxide (DMSO). To exclude effects of DMSO, a control group with this solvent was included.

\subsection{Origin of Broodstock and Eggs}

Noble crayfish (15 females and 6 males) were obtained from a hatchery in Schleswig-Holstein (Krebszucht Oeversee, Germany) in November and transferred to the facilities of Kiel University. Three groups of five females and two males were kept in three recirculating 600-L tanks throughout the reproduction period. Temperature was set at $8{ }^{\circ} \mathrm{C}$ and a light regime of $\mathrm{L}: \mathrm{D}=$ 10:14 was provided. Females were checked for eggs daily. Eggs were separated from females after a 2week period at $4{ }^{\circ} \mathrm{C}$ in winter, and artificial breeding was started in an incubator equipped with UV clarification, biofilter, oxygen supply and egg-moving trays.

Marbled crayfish were bred in the facilities of Kiel University; maternal animals were obtained beforehand in 2015 and kept individually in 12 separate $25 \mathrm{~L}$ aquaria in aerated tap water. The ambient temperature was $23{ }^{\circ} \mathrm{C}$; the light regime was $\mathrm{L}: \mathrm{D}=10: 14 \mathrm{~h}$. All animals were fed frozen midge larvae and peas ad libitum. Under these conditions, $P$. virginalis produced parthenogenetic eggs every 8-9 weeks in our laboratory. These eggs were separated $72 \mathrm{~h}$ after laying. 


\subsection{Experimental Design, Setup and Data Collection}

Separated eggs were transferred directly to twelve 12-well multititer plates (Greiner Bio-One, Kremsmünster, Austria) with one single egg per well; all eggs were randomly assigned to the wells. Stock solutions were made weekly for each concentration with twice the concentration of final TBA. Testing solutions were then prepared daily by diluting stock solution with a mixture of $30 \%$ tap water and $70 \%$ VE water, which we autoclaved. Each well was filled with $1.5 \mathrm{~mL}$ test-solution.

All multititer plates were placed in a laboratory shaker (Dual-Action shaker K 2, Edmund Bühler GmbH, Bodelshausen, Germany) that provided 60 movements per minute to ensure constant supply of oxygen and simulate parental movement of the abdomen. Experimental solutions were exchanged daily.

The transparent membrane of crayfish eggs enables us to examine the status of the embryonic development under a stereomicroscope (Alwes and Scholtz 2006). Using this method, we recorded developmental stages and mortality three times per week. We converted the developmental stages described by Sandeman and Sandeman (1991, noble crayfish) and Alwes and Scholtz (2006, marbled crayfish) into percentages to allow direct comparability of the embryonic development between species. Due to their different reproduction strategies, the development time of marbled crayfish $(650$ degree days) is three times shorter than the development time of noble crayfish (1900 degree days) (Skurdal and Taugbøl 2002; Kozák 2015). Therefore, we exposed noble crayfish for the duration of their complete embryonic development in one trial, and in another investigation, we exposed the embryos in the first, second and third phase of their development, resulting in equal exposure times of 15 days for each treatment (Table 1). Survival was also observed in the time after the exposure until the first moult. After this, the study was terminated. At this time, the fresh weight of the moulted animals was measured (Sartorius R160P-*D1 R160P Balance, Sartorius AG, Goettingen, Germany).

\subsection{Histology}

After 45 days of exposure, three noble crayfish juveniles from each concentration (24 in total) were fixated in formaldehyde (3.7\%) and decalcified for 2 weeks in Kristensens solution. After washing in phosphate buffered saline (PBS) three times for $15 \mathrm{~min}$, the animals
Table 1 Overview for trials per species and numbers per trial used during this experiment

\begin{tabular}{lllll}
\hline Species & $\begin{array}{l}\text { Trial } \\
\text { (days) }\end{array}$ & Designation & $\begin{array}{l}\text { No. per } \\
\text { concentration } \\
(8 \text { concentrations })\end{array}$ & $\begin{array}{l}\text { No. } \\
\text { trial }\end{array}$ \\
\hline P. virginalis & $0-15$ & PT & 36 & 288 \\
A. astacus & $0-45$ & AT & 12 & 96 \\
A. astacus & $0-15$ & A1 & 12 & 96 \\
A. astacus & $15-30$ & A2 & 12 & 96 \\
A. astacus & $30-45$ & A3 & 12 & 96 \\
\hline
\end{tabular}

were brought into an ethanol series $(2 \times 50 \%, 70 \%$, $90 \%, 2 \times 99 \%, 30$ min. each) and bedded in LR White in gelatin capsules as described in Table 2 (LR White acrylic resin, hard, Sigma-Aldrich, Germany).

Sections of $2 \mu \mathrm{m}$ were made using an ultramicrotome. Sections were stained with haematoxylin and eosin (HE) with an extended exposure time due to acrylic embedding in accordance with LR White instructions for use. Tissues of hepatopancreas were examined under a light microscope combined with a camera system (Leica DM1000 LED, Leica ICC50 HD, Leica Application Suite Version 3.0.0, Leica Microsystems CMS GmbH, Wetzlar, Germany). The examination of hepatopancreas cells included the observation of membrane damage, damage in the four different cell types and changes in size and number of the four different cell types per hepatopancreas compartment. For this procedure, 10 sections per individual were photographed and subsequently analysed by counting and measuring cells.

Table 2 Proportion of solutions, times and temperature for embedding juvenile crayfish in LR White. LR White Resin is a very low viscosity resin. For the embedding, it is applied in a mixture with ethanol to exchange ethanol stepwise in the sample, without causing damages

\begin{tabular}{cll}
\hline LR White: ethanol & Time $(\mathrm{h})$ & Temperature $\left({ }^{\circ} \mathrm{C}\right)$ \\
\hline $1: 2$ & 2 & 20 \\
$1: 1$ & 2 & 20 \\
$2: 1$ & 2 & 20 \\
$1: 0$ & 2 & 20 \\
$1: 0$ & 2 & 20 \\
$1: 0$ & 12 & 20 \\
$1: 0$ & 48 & 60 \\
\hline
\end{tabular}




\subsection{Statistical Methods}

We performed all statistical analyses using $\mathrm{R}$ ( $\mathrm{R}$ Core Team 2015). The weight of the juveniles and number of B cells per compartment were tested for normality and equal variances prior to analysis. Afterwards, a one-way ANOVA was performed and subsequently a Tukey post hoc test. For nonparametric data, a Kruskal-Wallis test was used. The $\mathrm{LC}_{50}$ values were control corrected using Abbott's correction first and then estimated utilizing the trimmed Spearman-Karber method. Survival rates were analysed using the Kaplan-Meier survival analysis of Gehan Breslow and the groups were compared via the Holm-Sidak method. The embryonic development was analysed via linear regressions. Due to good correlation values (> 0.8 ), the linear regressions were compared with an ANCOVA (analysis of covariances). Photographs were analysed in GIMP (version 2.8, Gimp Team).

\section{Results}

\subsection{Embryonic Development Time}

The development time of group PT (Procambarus virginalis total embryonic development time) embryos was not affected by any of the applied TBA concentrations. The development of group AT (Astacus astacus total embryonic development time) was affected by TBA concentrations with significant effects detectable at $6.4 \mathrm{mg} / \mathrm{L}$ and higher $(p \leq 0.028$, Fig. 1).

In detail, TBA did influence the last two-thirds of embryonic development. There were no differences in development of group A1 (first period of Astacus astacus embryonic development), but in group A2 (second period of Astacus astacus embryonic development), embryos exposed to the TBA concentrations of 6.4 and $12.8 \mathrm{mg} / \mathrm{L}$ developed slower in comparison to other groups $(p \leq 0.036)$. The exposure to TBA of group A3 (third period of Astacus astacus embryonic development) showed that the three highest concentrations significantly slowed down embryonic development $(p \leq 0.012$, Fig. 2).

\subsection{Weights}

Animals in group PT exposed to higher concentrations tended to have a lower weight at hatching (Table 3). However, the ANOVA did not reveal significant differences $(p>0.05)$.

Weights of noble crayfish were only recorded for groups A1, A2 and A3 because of an overall high mortality of noble crayfish of group AT. Group A1 was strongly impacted by TBA concentrations of $1.6 \mathrm{mg} / \mathrm{L}$ upwards resulting in a decline in mean
Fig. 1 Linear regressions of embryonic development of marbled crayfish embryos (PT) and noble crayfish embryos (AT) exposed to different concentrations of TBA over their embryonic development. Development of $100 \%$ is equivalent to hatching (AT: 12 individuals per concentration; PT: 36 individuals per concentration)

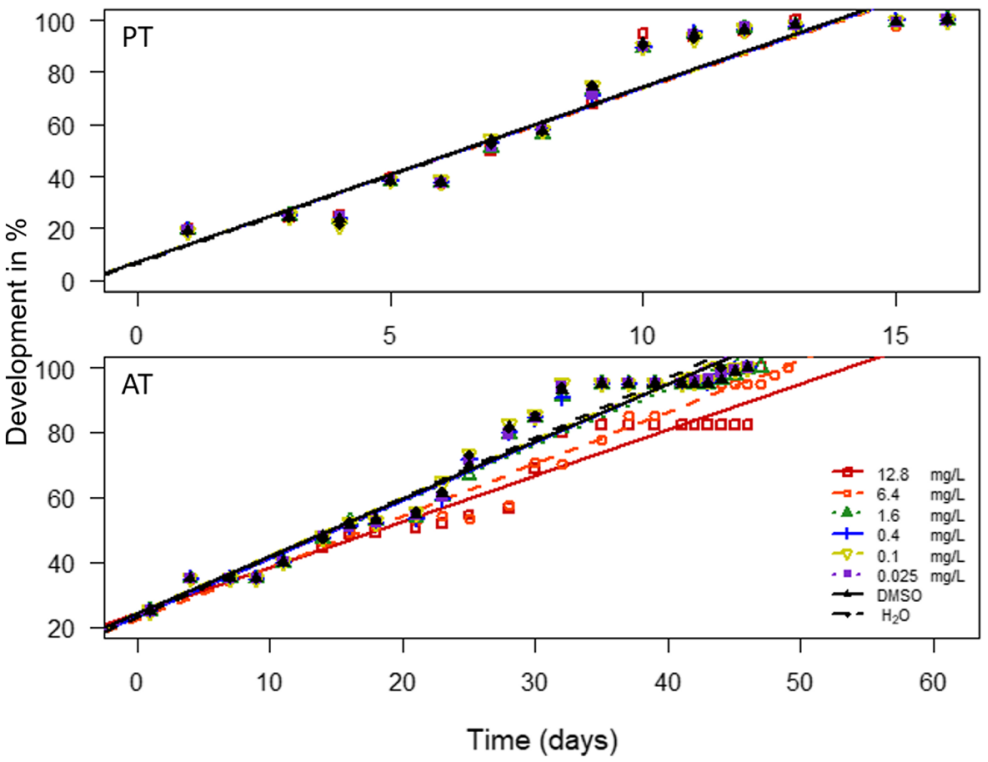


Fig. 2 Linear regressions of embryonic development of noble crayfish in different concentrations of TBA over time in first (A1), second (A2) and last (A3) third of development. Development of $100 \%$ is equivalent to hatching, whereas $110 \%$ development correspond to the first moult of juveniles (12 individuals per concentration)

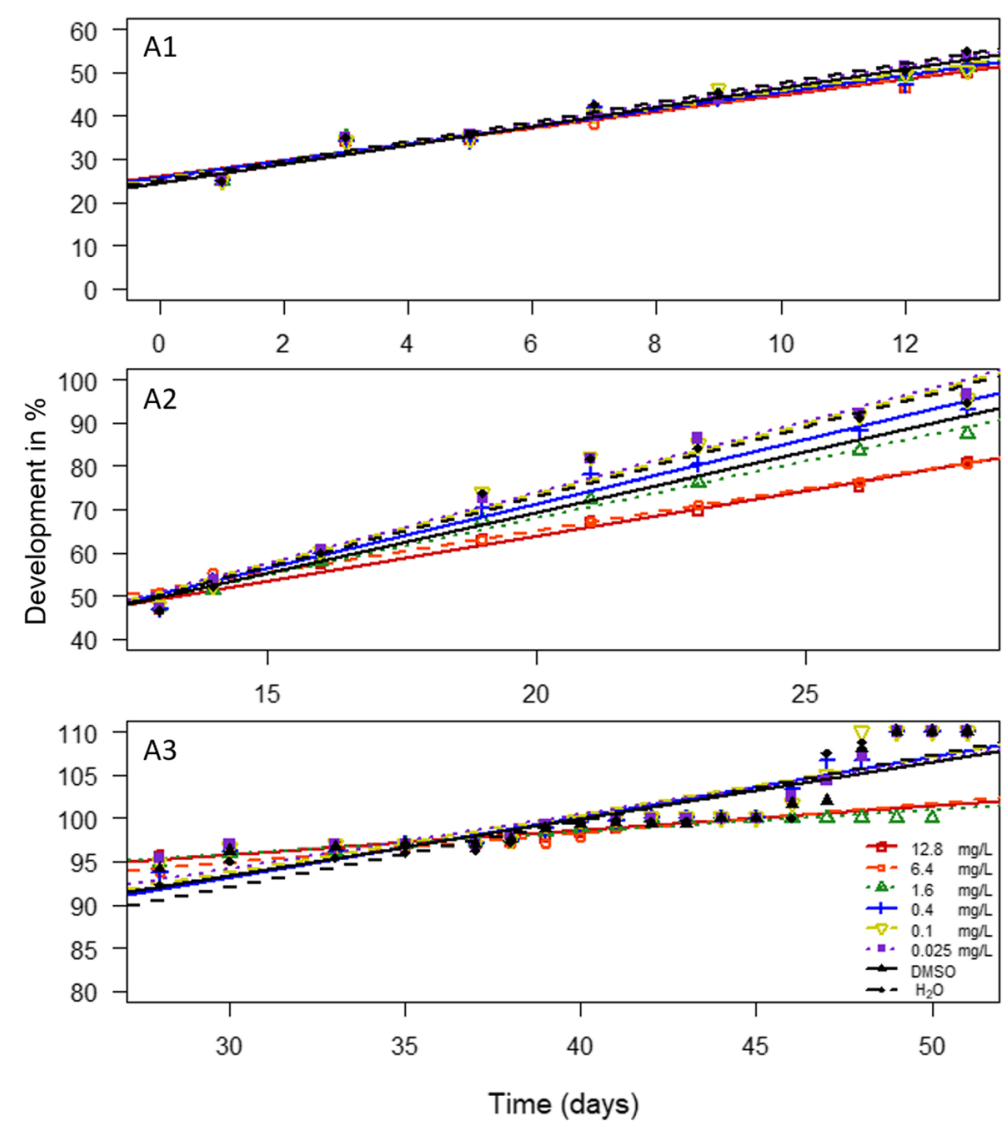

body weight of $46.36 \%$ compared to the control groups $(p \leq 0.0434)$. The influence on group A2 is limited to a concentration of $6.4 \mathrm{mg} / \mathrm{L}(p \leq 0.0256)$. In group A3, all individuals exposed to concentrations above $0.4 \mathrm{mg} / \mathrm{L}$ died before the first moult, and no differences in hatching weight were observed for the remaining concentrations.

\subsection{Survival Rate}

The survival rates of group PT exposed to different TBA concentrations are shown in Fig. 3. Both control groups and the lowest concentration supported the highest survival rates in a range between 60 and $66 \%$. The lowest survival rates were recorded at about $33 \%$ in treatments

Table 3 Average weights of juveniles of different trial in mg plus standard deviation at hatching referred to concentrations they were exposed to

\begin{tabular}{lllll}
\hline Concentration/Trial & A1 $[\mathrm{mg} \pm \mathrm{SD}]$ & A2 $[\mathrm{mg} \pm \mathrm{SD}]$ & A3 $[\mathrm{mg} \pm \mathrm{SD}]$ & $\mathrm{PT}[\mathrm{mg} \pm \mathrm{SD}]$ \\
\hline $0.00[\mathrm{mg} / \mathrm{L}]$ & $25.08 \pm 1.47$ & $23.53 \pm 2.17$ & $18.84 \pm 1.8$ & $3.54 \pm 0.55$ \\
$\mathrm{DMSO}[\mathrm{mg} / \mathrm{L}]$ & $24.00 \pm 0.57$ & $22.15 \pm 1.09$ & $19.60 \pm 0.79$ & $3.59 \pm 0.52$ \\
$0.025[\mathrm{mg} / \mathrm{L}]$ & $22.08 \pm 4.08$ & $24.34 \pm 1.32$ & $18.16 \pm 0.88$ & $3.45 \pm 0.60$ \\
$0.1[\mathrm{mg} / \mathrm{L}]$ & $22.03 \pm 4.17$ & $24.53 \pm 0.78$ & $19.78 \pm 0.74$ & $3.47 \pm 0.51$ \\
$0.4[\mathrm{mg} / \mathrm{L}]$ & $19.10 \pm 4.30$ & $23.62 \pm 1.08$ & $19.05 \pm 0.65$ & $3.50 \pm 0.43$ \\
$1.6[\mathrm{mg} / \mathrm{L}]$ & $17.35 \pm 3.99$ & $23.58 \pm 3.69$ & $/$ & $3.15 \pm 0.59$ \\
$6.4[\mathrm{mg} / \mathrm{L}]$ & $13.45 \pm 0.75$ & $20.58 \pm 2.15$ & $/$ & $3.14 \pm 0.60$ \\
$12.8[\mathrm{mg} / \mathrm{L}]$ & $15.65 \pm 3.25$ & $22.38 \pm 2.60$ & & $3.11 \pm 0.70$ \\
\hline
\end{tabular}


Fig. 3 Survival rates for marbled crayfish of group PT exposed to different concentrations of TBA during the experiment. The blue area shows the exposure time frames within the first 15 days. During the time after the exposure, embryos were kept without TBA influence ( 36 individuals per concentration)

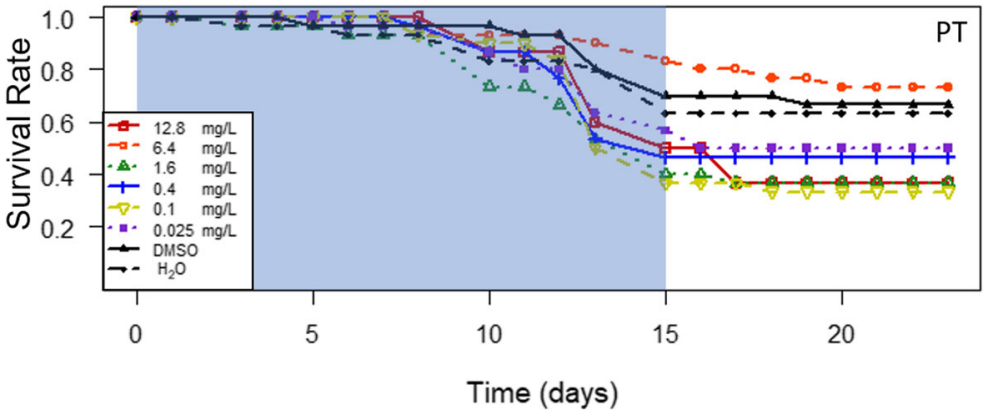

exposed to TBA concentrations of $12.8 \mathrm{mg} / \mathrm{L}, 1.6 \mathrm{mg} / \mathrm{L}$ and $0.1 \mathrm{mg} / \mathrm{L}$. Statistically significant differences to control treatment $\mathrm{H}_{2} \mathrm{O}$ were found for concentrations of $0.1 \mathrm{mg} / \mathrm{L}, 1.6 \mathrm{mg} / \mathrm{L}$ and $12.8 \mathrm{mg} / \mathrm{L}(p<0.02)$. The $\mathrm{LC}_{50}$ value for this group was $42.38 \mathrm{mg} / \mathrm{L}$ for 15 days of exposure. Due to the absence of a correlation between dose and effect, the standard error was greater than the estimated value $( \pm 66.00)$.

Survival rates in group AT (Fig. 4) were significantly lower than for marbled crayfish. Only individuals in the control group $\mathrm{H}_{2} \mathrm{O}(20 \%)$ and in the lowest concentration of $0.025 \mathrm{mg} / \mathrm{L}$ (10\%) completed the first moult. The two treatments with the highest TBA concentrations also showed significantly lower survival rates than the control groups and treatments with lower concentrations of $0.025,0.1$ and $1.6 \mathrm{mg} / \mathrm{L}(p \leq 0.043)$. The calculated $\mathrm{LC}_{50}$ (45 days) was $0.1110 \mathrm{mg} / \mathrm{L}(\mathrm{SD}=0.099)$.

When exposing the embryos of noble crayfish to TBA for timeslots of 15 days, higher impacts occurred in groups A1 and A3 during the entire development time. Within the first third, the survival rate dropped below $40 \%$ for every group (Fig. 5 a) with significantly lower survival rates in the three highest concentrations. If TBA exposure took place during the second period of development, only the group exposed to the highest concentration of $12.8 \mathrm{mg} / \mathrm{L}$ had a significantly lower survival rate, similar to the first third. In the final third of development, the three highest treatments showed a significant impact on the survival of noble crayfish embryos. $\mathrm{LC}_{50}$ (15 days) values $(1.051 \mathrm{mg} / \mathrm{L}$; $6.982 \mathrm{mg} / \mathrm{L} ; 0.257 \mathrm{mg} / \mathrm{L})$ for the three time frames showed a higher impact in the first and last part of embryonic development.

\subsection{Histology}

Figure 6 illustrates the effects of TBA on hepatopancreas structure of $A$. astacus. The average number of B cells per hepatopancreas cell of three noble crayfish juveniles from each concentration was estimated ( 24 in total). The control group showed an average of 24.6 B cells/ hepatopancreas cell. All sections of all concentrations showed a higher abundance of B cells and enlarged B cells compared to the control group (numbers are given in the supplementary material, Table 4). Starting at lowest concentrations of $0.025 \mathrm{mg} / \mathrm{L}$, the number of $\mathrm{B}$ cells per section (69.86) was significantly higher $\left(p<2 \mathrm{e}^{-16}\right)$ compared to the control group (24.6). This was also the case for all the other tested concentrations (0.1 mg/L: 69.86; $0.4 \mathrm{mg} / \mathrm{L}: 69.93 ; 1.6 \mathrm{mg} / \mathrm{L}: 71.56$; $\left.6.4 \mathrm{mg} / \mathrm{L}: 68.96 ; 12.8: 41.86 ; p<2 \mathrm{e}^{-6}\right)$. Even though the highest concentrations showed a number of $41.86 \mathrm{~B}$
Fig. 4 Survival rates for noble crayfish of group AT exposed to different concentrations of TBA during the experiment. The blue area shows the exposure time frames within the first 45 days. During the time after the exposure, embryos were kept without TBA influence (12 individuals per concentration)

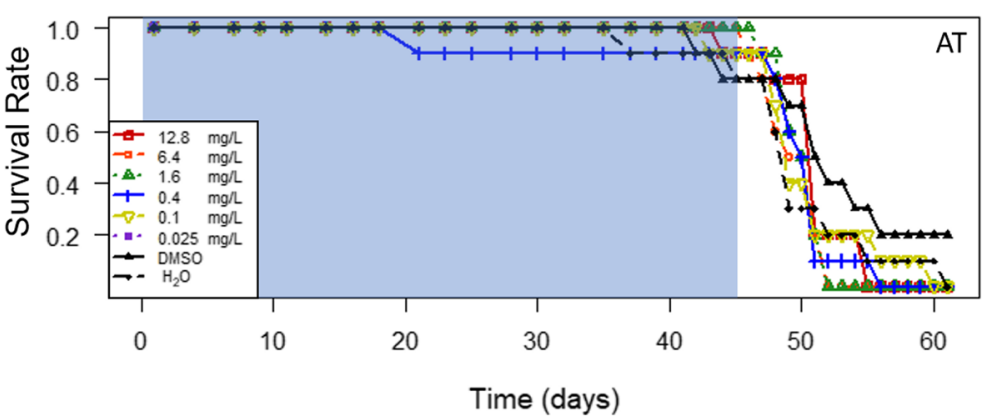


Fig. 5 Survival rates of noble crayfish exposed to different concentrations of TBA over time in first (A1), second (A2) and last (A3) third of development. The blue areas indicate exposure time frames. During the time after the exposure, embryos were kept without TBA influence (12 individuals per concentration)
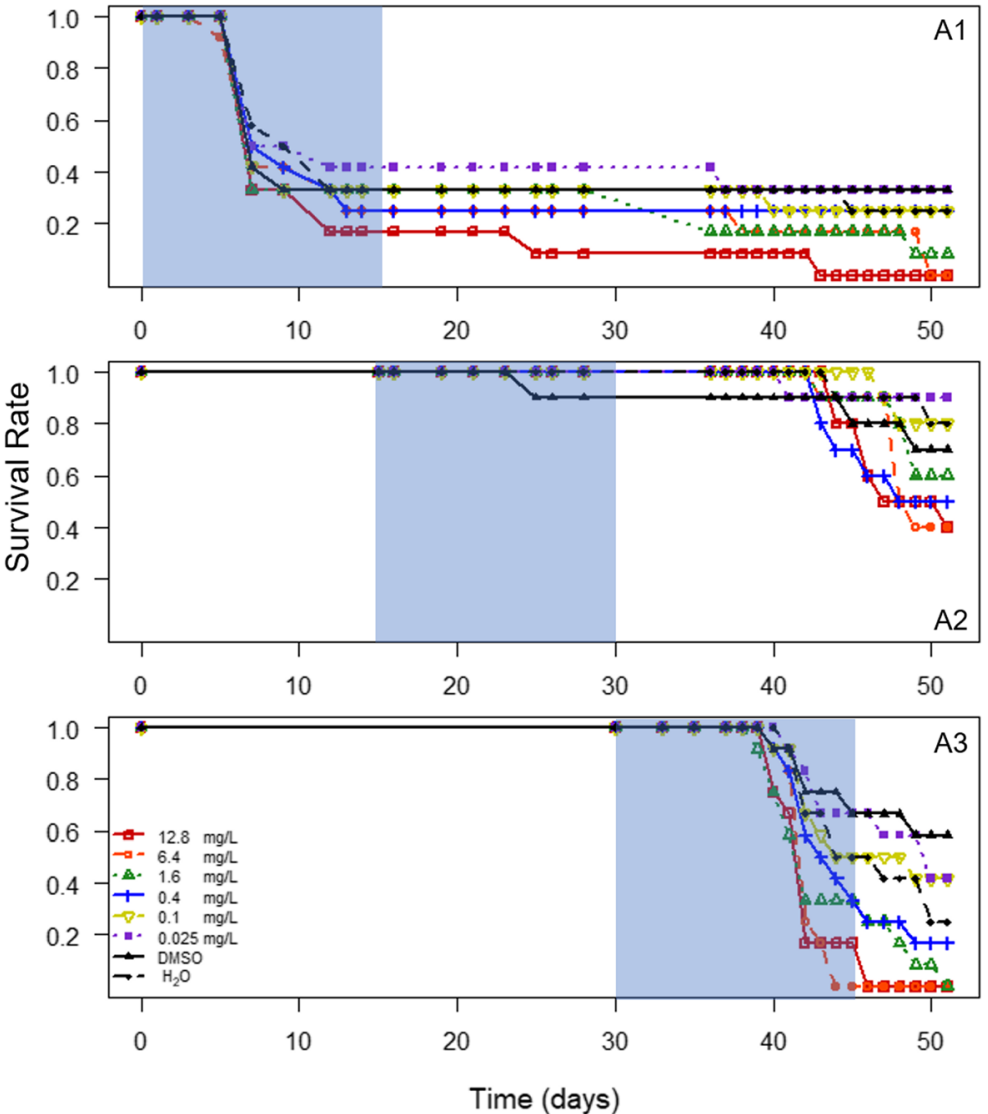

cells per section on average, the cells were about twice the size of the B cells in the control group. Additionally, no membrane disruption occurred in the control groups, whereas we observed disruptions at concentrations of $0.025 \mathrm{mg} / \mathrm{L}$ in $20 \%$ of all sections. At concentrations of $0.1 \mathrm{mg} / \mathrm{L}$, damages were visible in $34 \%$ of all sections and at concentrations of $0.4 \mathrm{mg} / \mathrm{L}$ in $62 \%$ of the sections. From concentrations of $1.6 \mathrm{mg} / \mathrm{L}$ upwards, this membrane damage was present in every section. Additional data are given in Online Resource 1.

\section{Discussion}

Our results highlight clear differences in sensitivity to TBA exposure between marbled and noble crayfish

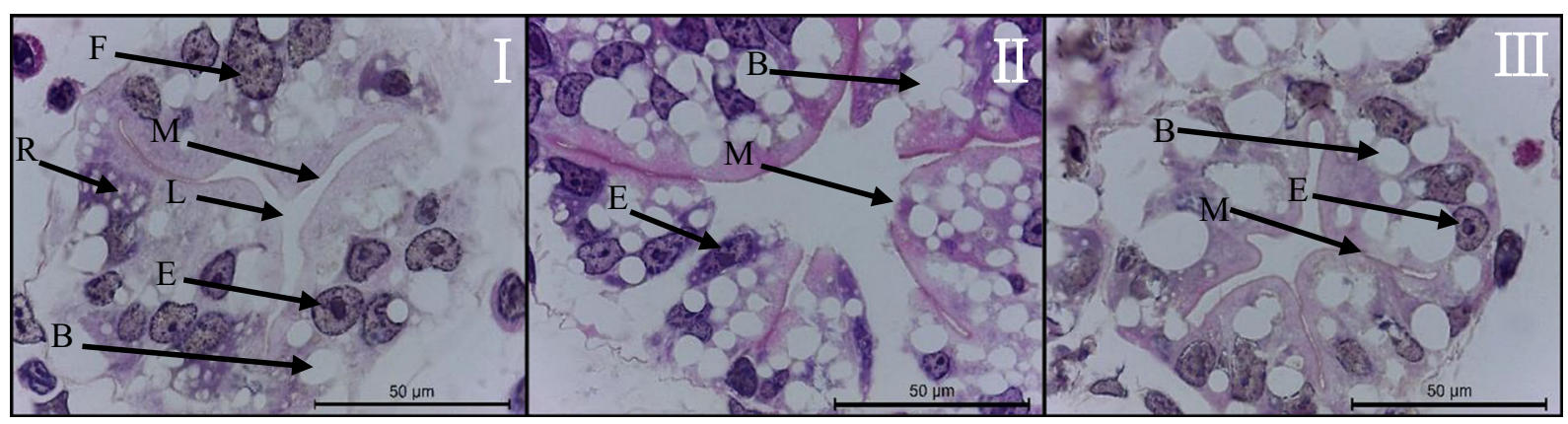

Fig. 6 Histological sections of hepatopancreas in juvenile noble crayfish (Astacus astacus) exposed to terbuthylazine for 45 days. I: control with marked lumen (L), membrane (M) and four types of epithelial cells: resorptive (R) lipid cells, blister-like (B) secretory cells, fibrillar (F) cells and embryonic (E) cells; II: group exposed to $0.025 \mathrm{mg} / \mathrm{L}$ TBA for 45 days; III: group exposed to $12.8 \mathrm{mg} / \mathrm{L}$ TBA for 45 days (HE stain, $\times 200 ; 3$ individuals per concentration) 
embryonic development. This questions the suitability of marbled crayfish as a model when studying environmental impacts on native freshwater crayfish such as noble crayfish. Even though genetic uniformity, ease of culture, and a broad behavioural repertoire encourage the use of marbled crayfish in epigenetics and developmental biology, as well as physiological, ecotoxicological, and ethological research (Hossain et al. 2018; Vogt 2008), the possibility of transferability of ecotoxicological effects to other species is questionable. The lower sensitivity of marbled crayfish compared to noble crayfish can on the one hand be explained by a 3 -fold longer embryonic development and therefore a longer exposure time of the latter. Additionally, Vogt (2010) described marbled crayfish as tolerant towards broad ranges of environmental conditions for long periods of time. Considering the results of Rubach et al. (2011) demonstrating that freshwater arthropod species can be highly variable in their dynamic response to a particular stressor, it is reasonable that the low sensitivity of marbled crayfish leads to lower effects of TBA on the organism than on noble crayfish, described as more sensitive overall (Holdich 2002).

It is evident, however, that TBA affects/slows down the overall embryonic development time of noble crayfish, while effects are strongest if animals are exposed during the second and final third of their embryonic development. In this phase, gastrulation is complete and all compartments of the crayfish's body are present, at least in rudimentary form (Alwes and Scholtz 2006; Sandeman and Sandeman 1991). Consequently, TBA is likely to hinder growth and specification of the compartments once their main structures are developed. This assumption is corroborated by the work of Gutiérrez et al. (2019), who described that TBA leads to biochemical changes in the species Scrobicularia plana, namely in protein contents and enzymatic activity levels, since the protein and enzymatic development take part in the later embryonic development of crayfish (Alwes and Scholtz 2006). The elongated embryonic development can be seen as a reason for the lower weights of juvenile crayfishes. Crayfish start feeding at the third juvenile stage. Up to this time, the embryo gets its energy from its extensive yolk reserves (Vogt and Tolley 2004). Lower weights of crayfish embryos caused by organic pollutants have been described previously (Velisek et al. 2017). Differences regarding the different concentrations of TBA were only present when noble crayfish embryos were exposed in the first period of their development. Here, gastrulation and the development of the immune system and excretory organs take place (Sandeman and Sandeman 1991). When considering results of the histology of the hepatopancreas, it is reasonable to assume that abnormalities of the hepatopancreas are connected to the lower weight of the hatched individuals. For outdoor populations, late hatching and lower weight can have serious consequences, since smaller and slower growing individuals have a lower survival potential due to lower feeding success and increased mortality through predation, as shown for marine fishes (Franke and Clemmesen 2011). For crayfish, it is also known that lower body weights from, for example, starvation cannot be fully recovered (Powell and Watts 2010).

As our data show, there is a higher influence of TBA for treatments $\mathrm{A} 1$ and $\mathrm{A} 3$ than on $\mathrm{A} 2$ in terms of mortality. Points in time of the highest mortalities correlate with gastrulation, biosynthesis and hatching (Alwes and Scholtz 2006), leading to the assumption that these stages are more sensitive to the potential pollutant than other stages. The usage as preemergence herbicide in March and April can at the same time lead to the highest concentrations of TBA during the first period of embryonic development (Ackerfors 1999). The combination of the resulting lower number of individuals, lower weight and later hatching eventuates in an even lower competitivity of noble crayfish against invasive crayfish species, whereas the interaction of native and invasive species is of severe conservation interest (Pacioglu et al. 2020).

The histology of the hepatopancreas shows effects even at lowest concentrations in the form of an increase in the number and diameter of B cells compared to the control group for every concentration of TBA for noble crayfishes. In addition, we found damage to membrane structures similar to Chaufan et al. (2006) for every concentration. Their study revealed disorganisation in hepatopancreas tubules as well as increased diameters and numbers of B cells on hepatopancreas cells after feeding crabs (Chasmagnathus granulatus) with hexachlorobenzen-contaminated Chlorella for 3 days. According to this result, an increase in the size and number of B cells is a sublethal effect of exposure to at least these two agricultural control chemicals. Silveyra et al. (2018) tested the influences of atrazine (which was substituted by TBA and is nearly similar in form and shape to TBA) on vitellogenesis, steroid levels and lipid peroxidation in female red swamp crayfish 
(Procambarus clarki). They found that atrazineexposed crayfish had a lower expression of vitellogenin in the ovary and hepatopancreas as well as smaller oocytes and reduced vitellogenin content in the ovary. This shows an additional effect on the hepatopancreas caused by chlorotriazines that can lead to decreased reproduction. They also showed that atrazine caused a higher metabolic effort in terms of lactate production, presumably triggered to provide the energy needed to face the unspecific stress produced by the herbicide. This higher metabolic effort, or trade-off effect, could explain the sublethal effects pointed out in this study. Besides terbuthylazine, the degradation products are of great interest due to their toxicity. Koutnik et al. (2017) showed that terbuthylazine-2-hydroxy-exposure in concentrations of down to $75 \mu \mathrm{g} / \mathrm{L}$ affected growth, ontogenetic development, the antioxidant system, and caused oxidative stress and pathological changes in the hepatopancreas of early life stages of marbled crayfish. Therefore, not only the herbicide itself is a threat to nontarget organisms but also the degradation product, which prolongs harmful consequences by the usage of herbicides containing terbuthylazine.

In surface waters of Spain, the maximal concentration of Europe with $34 \mu \mathrm{g} / \mathrm{L}$ of TBA was detected (Herrero-Hernández et al. 2017). With effects starting from $25 \mu \mathrm{g} / \mathrm{L}$, our data show that the TBA doses of European surface waters can have an influence on the remaining populations of noble crayfish, especially as these can often be found in areas influenced by agriculturally used substances (Skurdal and Taugbøl 2002).

The occurring effects at doses below surface water concentrations lead us to the conclusion that effects caused by chemical loads of surface waters have to be considered during the planning of reintroducing crayfish into surface waters. As Jourdan et al. (2019) stated in their review, the most straightforward explanation for reintroduction failure may be that the water quality requirements of the reintroduced species are not met. Micropollutants and pharmaceutical compounds are often not considered in water quality assessments due to the difficulty and costs involved in their measurement (Schwarzenbach et al. 2006; Verlicchi et al. 2012). To address this problem appropriately, the seasonal usage of different substances has to be taken into account. TBA, for instance should be monitored in spring during its main agricultural use.

In addition to these environmental reasons, the pollutants can be of economic importance as well.
Crustaceans represent $10 \%$ of the global aquaculture production (FAO 2018). In recent decades, crustacean aquaculture was developing rapidly worldwide and is considered to be an important food production sector in terms of sources of animal protein, occupation and financial gain and foreign exchange earnings (Kozák 2015; Wickins and O’C Lee 2003). Different crayfish species have been assessed for artificial breeding and cultivation programs as these animals are a wholesome and desirable food (Yazicioglu et al. 2018). Therefore, the testing of environmentally active compounds, including TBA, in crayfish production areas would be beneficial, not only for conservation purposes but also for economic reasons, such as food production.

In conclusion, TBA has an influence on the reproduction of the two freshwater crayfish species in all investigated parameters. Sublethal effects can be seen at every concentration, while their influence on future generations remains unclear. The wide range of effects of TBA on the embryonic development of freshwater crayfish shows the complexity of consequences caused by pollutants for these organisms. The length of time and type of use of TBA as a pre-emergence herbicide possibly leads to a generation of crayfish with variations in their hepatopancreas. This variation can again have influences on the respiratory activity and therefore on the overall fitness, especially of the endemic noble crayfish. The data of this study show the high risk of TBA on the non-target organisms that are crayfishes. Considering the important role of crayfishes for their habitat, the dangers posed by TBA for surface waters are highly relevant.

Supplementary Information The online version contains supplementary material available at https://doi.org/10.1007/s11270020-04921-3.

Acknowledgements Christian-Albrechts-University of Kiel provided logistical support for experimental and laboratory analyses. We would like to thank Helmut Jeske from Oeversee for the supply with noble crayfish, Frank Lenich for the supply with marbled crayfish and Glen Green, who improved the English.

Authors' Contribution All authors contributed to the study conception and design. Material preparation, data collection and analysis were performed by Jan Laurenz and Lena Lietz. The first draft of the manuscript was written by Jan Laurenz, and all authors commented on previous versions of the manuscript. All authors read and approved the final manuscript. 
Funding Open Access funding enabled and organized by Projekt DEAL. This study was funded by Deutsche Bundesstiftung Umwelt, PhD scholarship.

\section{Compliance with Ethical Standards}

All applicable institutional and/or national guidelines for the care and use of animals were followed.

Conflict of Interest The authors declare that they have no conflict of interest.

Supplementary Information The online version contains supplementary material available at https://doi.org/10.1007/s11270020-04921-3 .

Open Access This article is licensed under a Creative Commons Attribution 4.0 International License, which permits use, sharing, adaptation, distribution and reproduction in any medium or format, as long as you give appropriate credit to the original author(s) and the source, provide a link to the Creative Commons licence, and indicate if changes were made. The images or other third party material in this article are included in the article's Creative Commons licence, unless indicated otherwise in a credit line to the material. If material is not included in the article's Creative Commons licence and your intended use is not permitted by statutory regulation or exceeds the permitted use, you will need to obtain permission directly from the copyright holder. To view a copy of this licence, visit http://creativecommons.org/licenses/by/4.0/.

\section{References}

Abd El-Atti, M., Desouky, M., Mohamadien, A., \& Said, R. (2019). Effects of titanium dioxide nanoparticles on red swamp crayfish, Procambarus clarkii. Bioaccumulation, oxidative stress and histopathological biomarkers. The Egyptian Journal of Aquatic Research, 45, 11-18.

Ackerfors, H. (1999). Observation on the yearly life cycle of Astacus astacus in a small lake in Sweden. Freshwater Crayfish, 1999, 413-429.

Alwes, F., \& Scholtz, G. (2006). Stages and other aspects of the embryology of the parthenogenetic Marmorkrebs (Decapoda, Reptantia, Astacida). Development Genes and Evolution, 216, 169-184.

Calvo, N., Stumpf, L., Pietrokovsky, S., \& Greco, L. (2011). Early and late effects of feed restriction on survival, growth and hepatopancreas structure in juveniles of the red claw crayfish Cherax quadricarinatus. Aquaculture, 319, 355-362.

Cedergreen, N., \& Streibig, J. (2005). The toxicity of herbicides to non-target aquatic plants and algae. Assessment of predictive factors and hazard. Pest Management Science, 61, 11521160 .
Chaufan, G., Juárez, Á., Basack, S., Ithuralde, E., Sabatini, S., Genovese, G., et al. (2006). Toxicity of hexachlorobenzene and its transference from microalgae (Chlorella kessleri) to crabs (Chasmagnathus granulatus). Toxicology, 227, 262270.

Chucholl, C. (2011). Disjunct distribution pattern of Procambarus clarkii (Crustacea, Decapoda, Astacida, Cambaridae) in an artificial lake system in Southwestern Germany. Aquatic Invasions, 6, 109-113.

European Communities (1992) Council Directive 92/43/EEC of 21 May 1992 on the conservation of natural habitats and of wild fauna and flora. habitat directive.

FAO (2018). The State of World Fisheries and Aquaculture 2018 (Sofia): Meeting the sustainable development goals. Rome: Food \& Agriculture Organization of the UN

Franke, A., \& Clemmesen, C. (2011). Effect of ocean acidification on early life stages of Atlantic herring (Clupea harengus L.). Biogeosciences, 8, 3697-3707.

Gutiérrez, I., Mesquita, A., Nunes, C., Coimbra, M., Gonçalves, F., Marques, J., et al. (2019). Impacts of S-metolachlor and terbuthylazine in fatty acid and carbohydrate composition of the benthic clam Scrobicularia plana. Ecotoxicology and Environmental Safety, 173, 293-304.

Herrero-Hernández, E., Rodríguez-Cruz, M., Pose-Juan, E., Sánchez-González, S., Andrades, M., \& Sánchez-Martín, M. (2017). Seasonal distribution of herbicide and insecticide residues in the water resources of the vineyard region of $\mathrm{La}$ Rioja (Spain). The Science of the Total Environment, 609, 161-171.

Holdich, D. M. (Ed.). (2002). Biology of freshwater crayfish. Oxford: Blackwell Science.

Hossain, M., Patoka, J., Kouba, A., \& Buřič, M. (2018). Clonal crayfish as biological model. A review on marbled crayfish. Biologia, 73, 841-855.

Johnston, D., Alexander, C., \& Yellowlees, D. (1998). Epithelial cytology and function in the digestive gland of Thenus Orientalis (Decapoda. Scyllaridae). Journal of Crustacean Biology, 18, 271-278.

Jourdan, J., Plath, M., Tonkin, J., Ceylan, M., Dumeier, A., Gellert, G., et al. (2019). Reintroduction of freshwater macroinvertebrates: challenges and opportunities. Biological Reviews of the Cambridge Philosophical Society, 94, 368387.

Khan, S., \& Nugegoda, D. (2007). Sensitivity of juvenile freshwater crayfish Cherax destructor (Decapoda. Parastacidae) to trace metals. Ecotoxicology and Environmental Safety, 68, 463-469.

Koutnik, D., Stara, A., Zuskova, E., Kouba, A., \& Velisek, J. (2017). The chronic effects of terbuthylazine-2-hydroxy on early life stages of marbled crayfish (Procambarus fallax $f$. virginalis). Pesticide Biochemistry and Physiology, 136, 2933.

Kozák, P., Duris, Z., Petrusek, A., Buřič, M., Horká, I., Kouba, A., Kozubíková-Balcarová, E., Policar, T. (2015). Crayfish biology and culture. Ceske Budĕjovice: University of South Bohemia.

Lorente, C., Causapé, J., Glud, R., Hancke, K., Merchán, D., Muñiz, S., et al. (2015). Impacts of agricultural irrigation on nearby freshwater ecosystems: the seasonal influence of triazine herbicides in benthic algal communities. The Science of the Total Environment, 503-504, 151-158. 
Pacioglu, O., Theissinger, K., Alexa, A., Samoilă, C., Sîrbu, O.-I., Schrimpf, A., et al. (2020). Multifaceted implications of the competition between native and invasive crayfish. A glimmer of hope for the native's long-term survival. Biological Invasions, 22, 827-842.

Powell, M., \& Watts, S. (2010). Response to long-term nutrient deprivation and recovery in the crayfishes Procambarus clarkii and Procambarus zonangulus (Crustacea, Decapoda): component and proximate analyses. Journal of the World Aquaculture Society, 41, 71-80.

R Development Core Team (2008). R: A language and environment for statistical computing. R Foundation for Statistical Computing, Vienna, Austria. URL http://www.Rproject.org.

Rubach, M., Crum, S., \& van den Brink, P. (2011). Variability in the dynamics of mortality and immobility responses of freshwater arthropods exposed to chlorpyrifos. Archives of Environmental Contamination and Toxicology, 60, 708-721.

Sandeman, R., \& Sandeman, D. (1991). Stages in the development of the embryo of the fresh-water crayfish Cherax destructor. Roux's Archives of Developmental Biology, 200, 27-37.

Schramm, K., Behechti, A., Beck, B., \& Kettrup, A. (1998). Influence of an aquatic humic acid on the bioconcentration of selected compounds in Daphnia magna. Ecotoxicology and Environmental Safety, 41, 73-76.

Schwarzenbach, R., Escher, B., Fenner, K., Hofstetter, T., Johnson, C., von Gunten, U., et al. (2006). The challenge of micropollutants in aquatic systems. Science (New York, N.Y.), 313, 1072-1077.

Shehata, S., El-Dib, M., \& Abou Waly, H. (1997). Effect of certain herbicides on the growth of freshwater algae. Water, Air, and Soil Pollution, 100, 1-12.

Silveyra, G., Silveyra, P., Vatnick, I., Medesani, D., \& Rodríguez, E. (2018). Effects of atrazine on vitellogenesis, steroid levels and lipid peroxidation, in female red swamp crayfish Procambarus clarkii. Aquatic Toxicology (Amsterdam, Netherlands), 197, 136-142.

Simić, V., Maguire, I., Rajković, M., \& Petrović, A. (2015). Conservation strategy for the endangered crayfish species of the family Astacidae. The ESHIPPO crayfish model. Hydrobiologia, 760, 1-13.

Skurdal, J. \& Taugbøl, T., (2002). Astacus. In D.M. Holdich (Ed), Biology of freshwater crayfish (pp. 467-510), New Jersey: Wiley-Blackwell

Stepanova, S., Plhalova, L., Dolezelova, P., Prokes, M., Marsalek, P., Skoric, M., et al. (2012). The effects of subchronic exposure to terbuthylazine on early developmental stages of common carp. TheScientificWorldJournal, 2012, 615920.

Svobodová, J., Douda, K., Štambergová, M., Picek, J., Vlach, P., \& Fischer, D. (2012). The relationship between water quality and indigenous and alien crayfish distribution in the Czech Republic. Patterns and conservation implications. Aquatic Conservation: Marine and Freshwater Ecosystems, 22, 776-786.

Tasca, A., Puccini, M., Clematis, D., \& Panizza, M. (2019). Electrochemical removal of Terbuthylazine: Boron-doped diamond anode coupled with solid polymer electrolyte.
Environmental Pollution (Barking, Essex: 1987), 251, 285291.

Velisek, J., Kouba, A., \& Stara, A. (2013). Acute toxicity of triazine pesticides to juvenile signal crayfish (Pacifastacus leniusculus). Neuro Endocrinology Letters, 34(Suppl 2), 3136.

Velisek, J., Stara, A., Zuskova, E., \& Kouba, A. (2017). Effects of three triazine metabolites and their mixture at environmentally relevant concentrations on early life stages of marbled crayfish (Procambarus fallax $f$. virginalis). Chemosphere, 175, 440-445.

Verlicchi, P., Al Aukidy, M., \& Zambello, E. (2012). Occurrence of pharmaceutical compounds in urban wastewater. Removal, mass load and environmental risk after a secondary treatment-a review. The Science of the Total Environment, $429,123-155$.

Vogt, G. (2008). The marbled crayfish. A new model organism for research on development, epigenetics and evolutionary biology. Journal of Zoology, 276, 1-13.

Vogt, G. (2010). Suitability of the clonal marbled crayfish for biogerontological research. A review and perspective, with remarks on some further crustaceans. Biogerontology, 11, 643-669.

Vogt, G. (2015). Bimodal annual reproductive pattern in laboratory-reared marbled crayfish. Invertebrate Reproduction and Development, 59, 218-223.

Vogt, G. (2018). Annotated bibliography of the parthenogenetic marbled crayfish Procambarus virginalis, a new research model, potent invader and popular pet. Zootaxa, 4418, 301.

Vogt, G., \& Tolley, L. (2004). Brood care in freshwater crayfish and relationship with the offspring's sensory deficiencies. Journal of Morphology, 262, 566-582.

Vogt, G., Tolley, L., \& Scholtz, G. (2004). Life stages and reproductive components of the Marmorkrebs (marbled crayfish), the first parthenogenetic decapod crustacean. Journal of Morphology, 261, 286-311.

Weinländer, M., \& Füreder, L. (2016). Native and alien crayfish species. Do their trophic roles differ? Freshwater Science, 35, 1340-1353.

Wickins, J., \& O'C Lee, D. (2003). Crustacean farming, ranching and culture, 2nd edition. Aquaculture Research, 34, 269270.

Xiao, X., Han, D., Zhu, X., Yang, Y., Xie, S., \& Huang, Y. (2014). Effect of dietary cornstarch levels on growth performance, enzyme activity and hepatopancreas histology of juvenile red swamp crayfish, Procambarus clarkii (Girard). Aquaculture, 426-427, 112-119.

Yazicioglu, B., Kouba, A., KOZÁK, P., \& Niksirat, H. (2018). Post-mating spermatophore storage strategies in two species of crayfish. Implications for broodstock management. Animal, 12, 554-558.

Publisher's Note Springer Nature remains neutral with regard to jurisdictional claims in published maps and institutional affiliations. 